Franz Pichler Roberto Moreno-Díaz (Eds.)

\title{
Computer Aided Systems Theory - EUROCAST'97
}

\begin{abstract}
A Selection of Papers from the 6th International Workshop on Computer Aided Systems Theory Las Palmas de Gran Canaria, Spain February 24-28, 1997 Proceedings
\end{abstract}




\section{Series Editors}

Gerhard Goos, Karlsruhe University, Germany

Juris Hartmanis, Cornell University, NY, USA

Jan van Leeuwen, Utrecht University, The Netherlands

\section{Volume Editors}

Franz Pichler

Institute of Systems Science, Johannes Kepler University

Altenbergerstraße 69, A-4040 Linz, Austria

E-mail: pichler@cast.uni-linz.ac.at

Roberto Moreno-Díaz

Department of Computer Science and Systems

University of Las Palmas de Gran Canaria

P.O. Box 550, 35080 Las Palmas, Spain

E-mail: moreno@ciicc.ulpgc.es

Cataloging-in-Publication data applied for

\section{Die Deutsche Bibliothek - CIP-Einheitsaufnahme}

Computer aided systems theory : a selection of papers from the 6th International Workshop on Computer Aided Systems Theory, LasPalmas de Gran Canaria, Spain, Februrary 24 - 28, 1997 ; proceedings / EUROCAST '97. Franz Pichler ; Roberto Moreno Díaz (ed.). - Berlin ; Heidelberg ; New York ; Barcelona ; Budapest ; Hong Kong ; London ; Milan ; Paris ; Santa Clara ; Singapore ; Tokyo : Springer, 1997

(Lecture notes in computer science ; Vol. 1333)

ISBN 3-540-63811-3

CR Subject Classification (1991): J.6, I.6, I.2, J.7, J.3, C.1.m, C.3

ISSN 0302-9743

ISBN 3-540-63811-3 Springer-Verlag Berlin Heidelberg New York

This work is subject to copyright. All rights are reserved, whether the whole or part of the material is concerned, specifically the rights of translation, reprinting, re-use of illustrations, recitation, broadcasting, reproduction on microfilms or in any other way, and storage in data banks. Duplication of this publication or parts thereof is permitted only under the provisions of the German Copyright Law of September 9, 1965, in its current version, and permission for use must always be obtained from Springer -Verlag. Violations are liable for prosecution under the German Copyright Law.

(C) Springer-Verlag Berlin Heidelberg 1997

Printed in Germany

Typesetting: Camera-ready by author

SPIN $10647854 \quad 06 / 3142-543210 \quad$ Printed on acid-free paper 


\section{Preface}

The concept of "CAST - Computer Aided Systems Theory" was coined by one of the editors of this volume (F.P.) in the 1980s to start a program for the development of systems theory instrumented software for the design of engineering systems (CAST tools) and to integrate such tools with common $\mathrm{CAD} / \mathrm{CAM}$ environments. A goal of this initiative was to encourage systems theorists to implement their methods and to bring this to the awareness of practicing designers. Another was, to give systems theorists a chance to learn the needs for formal treatments of problems related to design activities on a systems level.

It was agreed that EUROCAST international conferences would be organized every two years, alternating between Las Palmas de Gran Canaria and a continental Europe location. Thus, successive EUROCAST meetings took place in Las Palmas (1989), Krems (1991), Las Palmas (1993), and Innsbruck (1995), in addition to an extra CAST Conference in Ottawa (Canada) in 1994. Selected papers from those meetings were published by Springer-Verlag as Lecture Notes in Computer Science volumes 410, 585, 763, 1030, and 1105, and in several special issues of the journal Cybernetics and Systems.

It was apparent since then that EUROCAST and CAST meetings were consolidated by the number and quality of contributions. This is confirmed in the present convocation, the last EUROCAST of the century in Las Palmas, in which the original scope has been widened to include systems technology.

An international ad hoc committee selected, on the basis of extended abstracts, 79 papers for presentation at the conference, from which 46 have been selected and are here included as post-conference full papers.

The topics cover a wide range of systems activities in the engineering field, which is shown by the different titles of the 6 parts. All in all, this collection of papers reflects the different possible perspectives on CAST research as seen from different fields of engineering activity. The editors of this volume express their thanks to all contributors to the conference, as well as to all participants; to the opening and keynote lecturers, Profs. José Mira, John Casti, and Achim Sydow, for their readiness to collaborate; to the sponsors; and in sum, to all those which contributed to make the conference a pleasant and useful scientific, technical, and human event.

Finally, the editors of this volume thank all contributors for providing the manuscripts in due time and to the staff of Springer-Verlag in Heidelberg for their valuable cooperation.

Franz Pichler 